hold process as pastcurization should so cleter the crusade for whole milk, and (3) to direct due attention to the menace of the prolific creamcry swill tank-pasteurized skim.

580 liederal Street.

\section{CERTIFIED MILK AND THE GENERAL MILK SUPPLY OF LOUISVILLE.*}

IIENRY GNOS TULEY, M.D.

Professor of Obstetries, Medical Department University of Louisville; Visiting Flysician to Foundlings Home and Masonic Widows and Orphans Home. LOUISVILLE, KY.

Milk is the most universally used commodity in every community, and the problems which confront the sanitarian in providing a city with a clean milk supply are many, varied and complex. The enormous mortality among infants during their first year of life is sufficient evidence of the importance of this subject. Harrington ${ }^{1}$ gives some very convincing statistical data, and Straus, of New York, gives the percentage of deaths during the tirst year as $3 \%$ per cent. of the whole number of births. Hence we believe that the consideration of this question by the members of this section will be productive of great good to all.

Lousville has just passed through a wave of milk reform which has resulted in a great improvement in its supply, and we do not believe that the results can be surpassed by any city in the country.

'To enphasize the necessity for reform it need only be said that the condition of the dairies in and around Louisville beggared description; they reeked in filth, the barns were most insantary and foul and the cows diseased and dirty. Yet milk produced under these conditions was being sold and consumed and our infant mortality kept up.

This appalling condition of aflairs was due to the universal use of distillery slop, or swill, as a food for these dairy cattle. The large number of distilleries on the outskirts of the city, with a thousand barrels of slop to be disposed of daily, caused a number of dairies to be established in the city limits and on the outskirts. Scrub cows, lean and often sick, were purchased in the fall and fed for from three to five months on distillery slop, the milk being sold as a by-product. The ultimate object of all the dairymen was to fatten the cattle for sale as beef later in the spring. Although there were ordinances on the city statutes specially prohibiting the sale of milk produced from swill-fed cows, the practice went on unabated.

Louisville has been slow to wake up to the needs of its health department and it was not until five years ago that the piesent efficient health officer, Dr. M. K. Allen, obtained sufficient appropriation for the establishment of a laboratory in connection with the department. Prior to this time, although the law prescribed the chemical standard of milk, there was no method by which the department could have the proper examinations made. Being greatly interested in the milk question, I frequently made the Babcock test for the department during the term of office of the predecessor of the present health officer, and on the strength of these examinations a few prosecutions of offenders against the chemical standards were instituted. Since the estab-

* Regd in the Section on Diseases of Children of the American Medical Association, at the rifty-eighth Annual Session, held at Atlantic City, June, 1907.

1. Boston Med. and Sirg. Journal, Feb. 1, 1906. lishment of the present laboratory in connection with the health department, and frequent prosecutions, the addition of water and preservatives to milk is practically discontinued, but the feeding of swill kept on.

I am firmly convinced that good milk can not be produced from cows fed on distillery slop, hulls, screenings, wet or dry brewer's grain or sour ensilage. I have frequently seen milk produced from swill-fed cows cause serious disturbances when fed to infants, while milk from cows properly fed would agree perfectly. Milk from swill-fed cows has an appalling bacterial content and is hyperacid.

'Those of you who have never visited a dairy barn, inhabited by cows fed on this slop, can not realize the conditions presented. It takes a barrel of swill a day to give a milk cow the equivalent of a properly balanced food. This very quickly causes an almost continuous diarrhea, the discharges being very acrid and foul. The cows are kept tied in their stalls practically continuously, and when turned out it is in a sea of liquid manure, as a rule. 'The barn reeks in liquid manure, the cows' flanks and udders are caked with liquid manure, the walls are spattered and the mist arising on a cool day from cows, floors and walls wet with the manure will make it impossible to sce clearly at a distance of fifteen feet. The odor is foul beyond description, and in this atmosphere the cows are milked, by dirty milkmen, in dirty, uncovered pails, which are emptied in dirty, uncovered cans standing in the corner of the barn. This milk is not cooled in winter or summer and is either retailed from a wagnn, drawn in measures from the large cans, or bottled from the can in front of the customer's residence. These facts are not exaggerated, and such milk was sold to Louisville infants and invalids until April 1, $190 \%$.

The public is largely to blame for this condition of affairs. As Coit says, however, "ignorance and greed in those engaged in the production of milk provails and its delicate nature is disregarded in the commercial expedients for its sale." A clean and cold milk can not be produced as cheaply as a dirty and contaminated milk, and the public, Harrington says, "prefers milk, plus cow-dung, at 8 cents a quart, to clean milk, not so flavored, at 9 or 10 cents."

The production of milk from swill-fed,cows was made possible by the existence of a Dairymen's Protective Association, organized to defend in the courts any action brought against the feeders of swill. That an amusing, though serious, condition existed was developed during the investigation, to be referred to later, in that the attorney for the dairymen's association was also the Louisville attorney for the State Board of Health and the State Pure Food Commission. Prosecutions were instituted, but, as was to be expected, convictions could never be obtained.

In 1891 I realized that a pure milk supply for babies could not be had through the ordinary channels, and in a paper in a symposium on milk before the Louisville Academy of Medicine, the late Dr. J. A. Larrabee, an ex-chairman of this section, also taking part, I suggested the appointment of a milk commission, under whose auspices a certified milk could be produced, but the plan did not meet with favor and was abandoned. About five years ago, still convinced of the practicability of the plan, I advocated it again before the Pathological Society. A commission was appointed by this society, but not receiving the support of the other members, who did not think the plan practical, it was again abandoned. 
I then endeavored to interest the State Pure Food Commission in the general milk supply of Louisville. Iater, on a request from the local health office, an active inrestigation was begun by Mr. R. M. Allen, of Lexington, assisted by a most intelligent and thorough corps of assistants. They began work two years ago, and at the July meeting of the Jefferson County Medical Society, a symposium on milk having been arranged, Mr. Ailen made his preliminary report. A most disgusting and dangerous condition of the dairies was shown, illustrated by a number of photographs. One hundred and one dairies were inspected, containing 2,800 cows, these supplying 5,031 gallons of milk, some direct to the consumer, some to the retail milk dealer. At 67 dairies, distillery slop was fed to 250 cows, producing 1,600 gallons of milk, and the condition of the barns and cows and the method of handling the milk was as outlined above.

At the conclusion of this meeting, on my motion, a committee was appointed to consider the practicability of having milk produced which could be certified as to its purity and which could come up to the proper chemical and bacteriologic standards and be produced and handled in a scientific manner. This committee reported at the next meeting that the plan was practical and urged the appointment of such a commission, that at least one milk supply could be obtained which could with safety be fed to infants and invalids. The committee was appointed as the first commission and it at once set to work to find a dairyman who would come up 10 the requirements. The society pledged its support to the commission and to Mr. Allen in his efforts to have a betterment in the general milk supply of the city.

With all of his data at hand, on the completion of the inspections and with the active and intelligent cooperation of Mr. Robert W. Bingham, county attorney, Mr. Allen brought his first prosecutions against the swill feeders in the court of County Magistrate Hollis. Every nember of the Dairrmen's Protective Association was cited to appear; ther were prosecuted and each confessed judgment of $\$ 100$ fine and fifty days in jail. On an earnest plea to suspend sentence until April 1. to give them an opportunity to clean up and to allow their contracts for swill to expire, the sentences were suspended until April 1. On April 1 a thorough inspection of the dairies on the black list was made by Mr. Allen, representing the Pure Food Commission, and representatives of the county, city and state health departments. Out of seventy dairies examined, eight were found with no attempt at cleaning up and the practice of swill feeding continued. They were cited to appear to show cause why sentence should not be imposed. All but one stated that they would either sell their cattle at once and quit the milk business or they would at once discontinue feeding swill and clean up. This one was placed in jail and the others were given a week to carry out their promises.

This fight has been gone into in detail because it is the history of a fight to save lives of thousands of bab es exposed to disease and death because of an impure milk supply. It was a fight of organized distillery interests, with slop for sale, an organized dairymen's association under contract to feed this swill, and political interests beyond finding out, against the law and an aroused pub. lic sentiment against the practice. Public sentiment in faror of pure milk is difficult to arouse, but the demand is slowly increasing. It is the majority of people in a community, howerer, who have no concern as to their milk, save that it does not sour in twenty-four hours and contains a fair percentage of cream, that the law and competent inspection must protect.

We are proud to say that to-day not a gallon of swill is being fed to dairy cows which supply milk to Louisville. It is true that there remains much to be changed in the methods of handling milk, for they are far from perfect at any of these dairies, but with the chief factor in the contamination at an end the possibilities are great for a permanent improvement in the supply. I believe the time will come when it will be illegal for any milk to be shipped which has not been bottled and sealed at the dairy. With the bottling at the dairy and the free use of ice great harm can be averted.

Another serious problem confronting us is the question of inspection of dairy cattle. Unfortunately, in Ientucky, the veterinary profession is not legally recognized, and there is no way to get at the charlatans and politicians among them. This, we hope, will be rectified at the next session of the legislature. The city requires regular inspection of the dairies and herds supplying milk to the city, but this inspection is a mere farce, as was stated by two veterinarians in attendance on the meeting of the State Veterinarian Association in Louisville recently. One man stated that "inspection of a dairy herd was easy picking; all that was necessary was to drive up to the fence, hail the dairyman, inquire the number of cows in the herd and write his certificate, receiving therefor 25 cents a head;" another said he "frequently took a pleasure drive in the country and picked up ten or fifteen dollars by inspecting herds while out." No wonder the dairyman has so little respect for the law when he is confronted each month with such wilful violation of it by supposedly honest men. The basis of good milk is a healthy herd, and unless there is honor among veterinarians this needed adjunct to obtaining a pure supply can not be had.

The question of tuberculosis among dairy cattle is a most serious one. 'The tuberculin test is so certain in its effect and so easy of performance that it should be more generally used. This will not be accomplished, however, until there is a state law whereby the owner of a condemned cow can be recompensed, in part at least, for the loss of his cow slaughtered under the tuberculin test. Steps are being taken now toward the preparation of such a bill to be introduced at the next session of the Kentucky legislature, with every hope of its passage, and an educational campaign has been begun among the farmers of the state to cause them to look on the bill more favorably.

The importance of the elimination of tuberculosis from dairy cattle has been brought forcibly to our attention in the report of the Commission on Tubereulosis from the British Medical Association, on the communicability of animal tuberculosis to man, and the confirmatory report of the investigations of Drs. E. C. Schroeder and W. E. Cotton, of the Bureau of Animal Industry of the Department of Agriculture at Washington. They state that "fresh tuberculous material has the highest, and dried and pulverized material a doubtful, significance," and that "man is constantly exposed to fresh tuberculous material in a helpless way through the use of dairy products from tuberculous cows and cows associated with tuberculous cattle." That tuberculosis is very prevalent among dairy cattle in Kentucky is eviclenced by the following figures, the results from tests made by Dr. F. T. Eisenman, state veterinarian, Dr. W. E. A. Wyman, of Covington, and Dr. D. A. 
Piatt, of Lexington. Dr. Wyman reports 109 tests with tubercular reaction in 69 , a percentage of 63 ; Dr. Piatt, 80 tests, 25 reactions positive, a percentage of 31 , and Dr. Eisenman reports 30 per cent. of all cattle tested have responded. The herd of the State Hospital at Stockton, Cal., showed a marked prevalence of tuberculosis, in every instance the autopsy findings bearing out the reaction.

I witnessed the slaughter of two cows condemned as tubercular after the test, whose milk had been sold in Iouisville only the day before. One of these cows showed an enormous cavity in one lung and a tubereulous udder, the other a well-marked mesenteric tuberculosis. With a competent law, intelligently administered, tuberculosis among dairy cattle can soon be eradicated.

It might be asked, "Why not pasteurize the whole city milk supply?" 'This question, I believe, has recently been discussed in New York City. In my judgment, it would be impossible to pasteurize the entire supply of a city, as there are so many sources of supply and so many small dealers who distribute the milk coming into the city. I believe that milk when pasteurized is so changed in its biologic, life-giving properties as to make it unfit for infant feeding any length of time. Clean milk is infinitely better than a cooked milk. Like Dr. Brush, I belicve that pasteurization of milk should cause it to be classified with canned foods which come under the head of embalmed beef, minus the chemicals, and that the Pure Food Commission should take the matter under advisement. Why infect milk with cow-dung and then kill the bacteria by pasteurizing? Another factor not generally thought of in connection with this question is that pasteurization lulls one into a belief that milk so treated is rendered good in spite of the manner in which it is subsequently handled. Pasteurized milk must be cared for with the same precision as clean cold milk to prevent further infection.

What has been said goes to prove that the problems involved in the production of a pure market milk are difficult of solution. Eternal vigilance, elimination of politics, a well-equipped laboratory, with a competent head to that department, veterinary inspection, proper laws and ordinances, education of the public and a public demand for pure milk, milk commissions, and education of dairymen, soliciting their cooperation rather than their antagonism, may produce a fairly good supply. However, it can not be too forcibly impressed that there may be adequate laws governing chemical standards, etc.; no good will be accomplished until inspection can be carried to the dairy, there to include regulation of everything pertaining to the herd, feed, production and handling of the milk and its shipment and handling until it reaches the consumer.

Milk which is properly produced can not be sold at a figure which will not work a hardship on the poorest classes, and to put milk within their reach at a nominal sum the milk dispensary is a great philanthropy. It is far better, however, to furnish these dispensaries with an inspected, clean milk, rather than endeavor to render harmless an infected milk by pasteurization or sterilization. If moneyed men and women in every community would establish or place the means at the command of a milk commission, to establish these milk dispensaries or lepots, where inspected, clean and cold milk can be had at a merely nominal price, the mortality among the infants of the poorer classes will be greatly reduced.

It is to the milk commissions, composed of doctors, disinterested financially, representing their county medical society, or its equivalent, that we must look for a limited supply of pure milk for infants and invalids. Too much can not be said in praise of Dr. Henry L. Coit, who first suggested the possibility of producing a mi!k which could be certified as to its chemical and bacteriologic purity and first put the scheme into practical operation. The organization of the medical milk commissions in Louisville at this time is to be commended, and we belicve the good work they have done will be rendered more uniform and similar commissions formed at many. other points.

The milk commission of the Jefferson County Medical Society, of which I am a member, has done a good work. This commission issued its first certificate Sept. 1, 1906, this dairyman beginning with fifteen gallons a day. It is now certifying to the product of three dairies, this being delivered by two firms, one of which handles only certified products.

The rules of the commission are not too rigid, yet the results will compare favorably with those of other commissions. All cows must be healthy and tuberculin tested; the barns clean, with concrete floors, properly drained, well lighted and ventilated; walls whitewashed or painted with sealed ceilings; the milkers healthy and clad in clean white suits; the use of the Gurler milk pail; the milk cooled and aërated to 46 degrees fifteen minutes after milking and bottled and scaled at once and kep't at this temperature until delivered to the consumer. The butter fat must be between 3.5 per cent. and 4 per cent.; the total solids not less than 12 per cent.; the bacterial count of milk not more than 10,000 per c.c., and of cream not more than 15,000 per c.c. Bu't few times since issuing the first certificate has the count exceeded the limit, and each time some error in technic could be found on investigation. Once the count of one dairy reached 27,000 per c.c., and, taking this into consideration, the average count for twenty-seven consecutive days was less than 10,000 .

Mr. Clarence B. Lane, of the Department of Agriculture, at Washington, recently examined one of the dairies and gave it 99.4 out of a possible 100 points.

With all of this we are not satisfied, our aim being to bring the entire city's supply as near perfection as possible.

In this connection I wish to call attention to the notable gathering, held at the St. Charles Hotel, Atlantic City, N. J., on June 4, 190\%, when the American Association of Medical Milk Commissions was formed on a permanent basis. Twenty-five milk commissions were personally represented, and every one on the program was present with his paper.

The admirable work of Dr. Coit, fourteen years ago, is now bearing rich fruit. It was an inspiring sight to see so many of the foremost scientists in the country, with the altruistic purpose of benefiting the health of the community and reducing our infant mortality by improving the milk supply. With the formation of this national body, the work of the commissions generally will be standardized, chemical and bacteriologic methods and standards equalized, missionary work in undeveloped territories is made possible, and the furthering of the movement and formation of new commissions on a sound basis encouraged. Printed reports of this meeting of the commissions have been ordered by the council and a closer federation of all will be had.

I earnestly urge the serious consideration of the question of medical milk commissions in all cities, their ap- 
pointment and support by the county medical societies, and the improvement of at least one milk supply for clinical purposes. By such a course, by example, an improrement in the general milk supply will certainly follow and great good to the infant popinlation of every (ommunity obtain.

Correspondence with the secretary of the national hodr, Dr. O. P. (Geier, Cincinnati, is urged on those interested in the question.

\section{DISCUSSION}

ON PAPERS OF DRS. MC ALISTER AXD TULEY.

Dr. Theonore Le Boutrleier, Philadelphia, insisted that it is time that medical men should decry the wholesale pas. teurization of milk; for, in the large eities at least, pasteuriza tion is anything but cleanly-the milk goes in in bad condi tion and when it comes out it is infinitely worse, sometimes containing three times as many bacteria. The can, as a rule, is not elean. The milk is made worse in every way. It makes the people at large have more faith in the milk when it is certainly not so good and not so healthful for the infants. Pas. trurization, if necessary, should be done at home. As a rule, in pasteurization plants the milk simply passes through coils of heated pipes for two minutes and is then said to be pas. teurized. In Dr. Tuley's paper he commended inspected milk berause this is something that is needed. The poorer classos. (an not pay 14 to 18 cents a quart for milk. This will be of much benefit, particularly in dispensary work, and it will also help to educate the people at large, and later those who can allord it will pay more for the certified milk.

DR. G. Lloyd MaGruder, Washington, D. C., said that this subject was agitated recently in Washington in a manmer which, he thought, will bear fruit for the comtry. The District Commissioners invited, for the purpose of conferring on the milk supply, a number of leading citizens, including representatives of the various departments of the government and members of the-medical profession and other scientific societirs. This committee of about luv was divided into various subcommittees, including one on infant teeding and another on the sanitary condition of the milk supply. The Committee on Infant Feeding unanimously recommended the use of certified milk for children under 3 years. This milk was to be subjected to most rigid inspection by the health officer. The Committee on the Sanitary Condition of the Milk Supply recommended repeated careful inspection of the conditions at the farm, this inspection to include the health of the people, the character of the barns, the water supply, as well as the condition of the cattle, the methods of transportation and the recep$t i m$ and distribution of the milk in the city. From the information obtained the committee recommended that milk should be divided into three classes: (1) rertified milk, (2) milk from tuberculin tested cows to be produced under careful situitary conditions not as exacting as for certified milk and to contain not over 100,000 bacteria to the c.c. when delivered at $50^{\circ} \mathrm{F}$., (3) milk from all other sources. From this third (biss certain milk was excluded. On account of the quality of this third class, compulsory pasteurization was advocated under the supervision of the health officer, preferably in a central plant. The futility of pasteurization without skilled supervision was fully appreciated.

D). R. B. Gilbert, Louisville, Ky., stated that Dr. Tuley deserves great credit for what he has assisted in achieving toward getting pure milk in Kentucky. Dr. Gilbert has made some personal observations of these various dairies and found conditions appalling. In addition to foul odors, there were 11:e mud and filth surrounding the cows, and in the summer myriads of flies drop into the milk supply. But there has licen a great improvement under great difficulties. One of the bourd of Aldermen of Louisville who is manager of a large distillery upholds strongly the ordinance prohibiting the feed ing of slop to the cows, the idea being that the source of supply is essential to getting wholesome milk. The cow must be healthy. and the surroundings where the milk is obtained and hancled must be sanitary. This being done, he said the queslion of pasteurization would be retired to the rear.
Dr. I, C. AGEr, Brooklyn, N. Y., mentioned one point that had not been touched on, and that is. what is to be done about country milk? It is a fact that it is often easier to get good misk in the city than in the country, and a child is sent to the country to better its condition, and it becomes worse. It is almost impossible to get good milk in the country. It is a poor grade of milk. The fat perentage is low-even in a grazing country anywhere near large eities-the best milk goes to the eity, the poor milk is sold in the neighborhood, and it is a serious menace to the health of the infants. In New York, he said, the use and sale of skim milk is strictly prohibited.

Dr. Ager agreed with Dr. Tuley on one point, and that is that public opinion is difficult to arouse. He finds that public opinion is aroused easily if it is done in the right way. Public opinion can not be aroused at a physicians' meeting; it must be done at a public meeting.

Dr. Alfred Friedlander, Cincinnati, said that the formation of the Cincinnati commission was rendered more difficult becanse three-fourths of the dairies were slop-fed dairies, and the conditions were practically as Dr. Tuley described. Eiforts to prohibit siop-feeding were rendered nugatory by the distillery interests, which were powerful enough, through political agencies, to head off the attempt. The commission had to work from the standpoint of education. The commission has been certifying two grades of milk: first, a certified milk, and, second, an inspected milk. This inspected milk is received with great fivor by the public. The requirements for inspected milk are practically the same as for certified milk ixcept the bacteriologic standard. For the past four months the milk has conformed in every respect to certified milk. Another point of value, Dr. Friedlander said, is the inspection of bulk milk for the use of hospitals and public institutions. The Cincinnati commission now issues certificates to dealers for hospitals and institutions shipping milk in cans the same as for inspected milk. 'The commission cherished the hope that at an early date, through the agency of one of the large charitable institutions, it will directly supply the poor with this better grade of milk.

Dr. T. W. Kiluer, New York City, pointed out that even when clean milk is delivered at the house the people must be instructed how to take care of that milk. The mortality proposition, he said, seems to consist of ejean milk and instruction to the people how to keep it clean. This is especially true in the lower classes. Boards of health, especially in New York, have done a great deal to lessen mortality, but, he said, the instruction of the Board of Health should not be spasmodic during the summer months, but should be continued during the winter months, so that when summer comes the mothers will know what to do.

Dr. Inomas S. Soutirwortir, New York City, stated that in the city of New York there has recently been a strong morement for pasteurization of the entire milk supply other than that certified by the County Medical Society. The soures from which this demand for pasteurization os the entire milk supply came were three in number: (1) Those who conscientiously believed that the pasteurization of milk is even more of a life-saver for infants than its modification; (2) those dealers who were planning to put out pasteurized milk in large amounts, and (3) the manufacturers of pasteurizing macilnes. All of these groups were represented strongly in the series of meetings before the aldermen and pusned the matter actively, although not always under their true colors. To show how imperfectly the question was understood, ])r. Southworth eited the case of one of the gentlemen who introduced one of these measures which should make it obligatory to pasteurize the entire milk supply. He was asked during the discussion what would happen provided a can of pasteurized milk was left open and dust blew into it. He hesitated a moment and then said he believed that germs did not grow as well in pasteurized milk as in raw milk, showing what misronceptions exist in the lay mind. There is one thing, J)r. Southworth said; which must be differentiated clearly in discussion, and that is the difference between the pasteurization of milk before it is sent to the consumer and the pasteurization of infanes' bottles after all manipulation of the milk has been rompleted. 
Dr. Ciras. K. Jorrsson, Burlington, Vt., said that a short time ago, at a meeting of the county medical society and dairymen and milk dealers, the production of certified milk was discussed, and all the dairymen seemed anxious to help in the work.

Dr. W. G. Murphy, East Hartford, Conn., cited cases of interest recently in his section of the country. The first was that of a cow which reacted to the tubercuiin test and was killed. At the autopsy no evidence of tuberculosis could be found in lungs, glands or mesentery. It was not until the udder was opened that the cause was discovered; there, adjacent to and almost immediately attached to a milk duct, was a large abscess containing something like half a pint of pus. It is not necessary, he said, to go very far to see the result if this abscess had broken while the animal was being milked. The second case was one of a cow sold ty a dairyman to a butcher: The cow was in such miserable condition that she fell on the way. The man who had her in charge was arrested for cruelty to animals and convicted. The cow, on examination, was found to be tuberculous, the lungs diseased, an abscess gathering in the liver, and an abscess in the shoulder. That cow was milked up to the day she was sold. She was sold for $\$ 7$.

The question is, how can such things as these be avoided? Dr. Murphy thinks that the only safeguard for physicians who are using milk for infant feeding is certified milk or muk controlled by the milk commission.

Dr. Elias H. Bartiey, Brooklyn, N. Y., suggested taking a definite stand on this question of pasteurization. While the education of the public is desirable, and while it is going on rapidly, medical men must be a little bit cautious as to what direction they educate the public. In New York this winter it was suggested to force pasteurization of the whole milk supply at enormous cost and questionable benefit. It required a great deal of argument to prevent this resolution being adopted. Certain financial interests behind it came very near forcing it through. There was at that time no unanimity of opinion among the medical profession as to what was best to be done. A few physicians who appeared before the Common Council at the hearing opposed it on the general ground of injury to the milk, and yet they were somewhat timid in saying that pasteurization is not a good thing. Dr. Bartlett thought that the District of Columbia has come pretty near settling something definite, classifying milk. He considers it very desirable to classify the markel milk and then pasteurize that which is below a certain standard. But, he asked, who is to classify it? It can only be done by inspection of the dairies. If this can be made practicable in large supplies, it may solve the difficulty. Dr. Bartlett is willing to admit that it would be best to pasteurize all the dirty milk, and by so doing advertise that pasteurization is simply an apology for dirty milk. He thinks that one of the greatest benefits of the milk commissions to the community has been the education of the public, the education of the milk producer and the consumer. This has already shown great results.

Dr. C. Wm, Brown, Elmira, N. Y., regretted that there is not a greater unanimity of opinion among the men who have paid special attention to this subject. The day before, at a symposium on tuberculosis, speaker after speaker demanded pasteurization of all the milk to get rid of possible danger of tuberculosis. This body, largely interested in feeding children, protests against the universal pasteurization of milk; so that it seems that the medical profession, as a whole, has no ideal. Is the ideal, he asked, pasteurization of milk to kill a certain number of bacteria and germs of tuberculosis, or is the ideal to get rid of tuberculous cattle that there may be no possible infection from that source? For this reason, while the work of physicians in Louisville and other cities is to be highly commended, it has always seemed to Dr. Brown a matter of great importance to get at the source first. In cities the size of Louisville, he said, there is no reason for having third class milk. There should be good milk and bad milk. Milk from tuberculous animals should not be sold.

Dr. J. W. VAN Derslice, Oak Park, Ill., sounded a note of warning about the selling of pasteurized milk. The first and second grades, he said, are sold to those who can afford to buy them, and the third grade is sold to the poorer people and those who have the least idea of bacteriology. If plysicians approve of pasteurized milk, in the minds of many in the large eities it will mean that something has been done to the milk by which no harm can come from using it, and they will not give it the care necessary to keep it from contamination.

To the lay mind it will be all sufficient that it was pasteurized. This, coupled with the fact that because of the destruction of the ferments by the heat the milk will not, by any plyysical change, show the harmful effects of contamination makes it possible for great harm to come to those phyicians are striving to protect.

Dr. L. Boonse, Milwaukee, Wis., agreed that there can be no question about the value of certified milk, but, he said, this is not available to all consumers. With a view of improving the general supply in Milwaukee, an ordinance was recently passed requiring the testing for tuberculosis of all cows from which the milk supply of the city is derived. The Health Department sends inspectors to the dairies to ascertain the sanitary conditions before a license is issued. The milk is examined both chemically and bacteriologically, and the health officer has the power to revoke the license of dairymen who do not meet the requirements as regards the quality of the milk or the sanitary condition of the dairy.

DR. R. M. Merrick, Boston, Mass., said a word in favor of the recognition of inspected milk. A milk conmission in Boston of which he is a member has been inspecting farms with regard to the general hygiene and the cleanly care of the milk, and has been recommending the clean and careful producer. The reeognition alone of certified milk by a milk commission at present means a very limited supply of high-class milk at a greatly increased price. With the recognition of "inspected milk" physicians get a large supply of clean milk at a moderate increase in the price. The certified milk is best, but the small supply and high price limit its usefulness. It is better for physicians to have inspected milk for use than to trust themselves to an unknown and otten filthy milk supply. Inspected milk will, he said, lead to certified milk, but until the supply of certified milk becomes larger and the price lower, the recognition of inspected milk will promote the increase of clean milk and do away with the using of dirty milk.

Prof. C. B. Lane, Washington, D. C., referring to Dr. Tuley's paper, said that he (Tuley) outlined the condition of dairies around Louisville and stated that 67 out of 100 are unclean, but instead of looking on these conditions as insurmountable they simply went to work and cleaned them up. The same thing can be done in any city. As to certified milk, he said that what is needed in milk production to-day is not nore expenditure, or better architecture, but cleaner cows and cleaner barns and more sanitary conditions all around. While in Louisville Professor Lane went to see one of the sanitary plants, and as he approached the place the barn loomed up, one of the old-fashioned kind. He expected to find old-time conditions, but was agreeably surprised. Windows had been put in this old barn; every cow had four square feet of glass. There were cement floors, good stalls, and everything was clean. Around other cities, he said, there are hundreds of dairies which could, at very little expense, be brought up to a high grade and produce certified milk.

Of the three classes of milk which have been mentioned, certified, inspected and the ordinary class, the producer can take his choice and produce certified milk at 8 or 10 cents a quart, or inspected milk at 6 or 8 cents, or dirty milk at 4 to 6 cents a quart. The consumer can also take his choice. As it is now, there is not one city in ten where there is any attempt made at grading the milk. The dirty sells for the same price as the clean. The consumer has no way of knowing the difference. In a town in New Jersey the names of all the dairy. men are published, with the rating of their dairies and the average bacteria present in each producer's milk, monthly and yearly. A statement is also included of any prosecutions made, so that the public can know what is going on. Professor Lane believes in exposing these things. Both dairyman and consumer should know all about the products they handle. 
Dr. Cirarles G. Kerley, New York City, took issue with Professor Lane in regard to the supply of milk to poor people. They do not know what good milk is. They have the loast money and the most babies, and the state is in duty bound to protect the ofispring of the poor. This work is for the protection of these poor children who have no means of protection from their own people, because of the unfortunate situation in which they are born, and which is no fault whatever of theirs.

Dr. A. C. Mercer, Syracuse, N. Y., made a suggestion, and that is that physicians insist that pasteurized milk is simply renovated milk. This pasteurized or renovated milk business he said, may be likened unto a lady going to a bonnet shop and buying a bit of ribbon and trailing it through the mud on the way lome, then trying to wash and iron it and put it on a hat, instead of keeping it clean from the beginning.

Dr. Alexaxder McAlister, Camden, N. J., referring to the sale of skim milk, said that there is a law in Pennsylvania and New Jersey requiring that all skim milk be labeled, and any milkman found selling skim milk without being labeled as such is fined.

Dr. Henry F. Tuley, Louisville, Ky., thought that Washington is many years behind the times. With the many departments of the government at its command, it should have begun this work long ago and been an example to other cities of what good could be accomplished. As to pasteurization, New York City, he said, has disposed of the question of wholesale pasteurization most satisfactorily. The health department of that eity, after conference with members of the medical profession and the milk commissions, has asked for a large appropriation, something like $\$ 1,000,000$, which is to be expended in the inspection of dairies. This is a wise decision and it is believed that the result will justify this large expenditure. At a conference of medical milk commissions the Cincinnati members reported the results of a very interesting investigation of milk delivered to several hospitals and its condition when it reached the various floors for distribution to the patients. The increase in the number of bacterii between the time of its delivery to the hospital and when delivered to the patients was enormous. Dr. Tuley is convinced that public opinion is a difficult thing to arouse, in spite of what has been said. It is especially difficult to educate the poor in regard to milk. An important item to them is the cost of the milk. It is absolutely impossible to produce a clean, cold, wholesome milk cheaply. The question of the price of certified milk has agitated the Louisville Milk Commission not a little. The price has been placed at 10 cents a quart to consumers. The producer gets 2: cents a gallon, the distributor 15 cents a gallon. Both the producer and the distributor are under control of the milk commission. A clean, cold milk can not be produced for less than 8 cents and possibly 10 cents a quart. Milk fit for consumption can only be had at prices eheaper than this when philanthropic people and societies aid the poor. The question of tuberculosis in dairy cattle is most important, and Dr. Tuley urged that the public be educated to the dangers which lie in a milk supply coming from a non-tuberculin tested herd.

Special Diets in Hospitals. $-A$ committee was appointed by the French authorities, in 1903, to suggest modifications in hospital diets. The recommendations of the committee were adopted and attempts have been made to introduce them gradually in the Cochin Hospital. Eight different diets were proposed by the committee, the diet for healthy persons, for convalescents, for dyspeptics, for the tuberculous and for diabeties, the milk-vegetable diet, the exclusive milk diet and the salt-frce diet. The results have been eminently satisfactory. The salt-free diet is a recent suggestion on the part of the committee, as also the addition of bouillon to the diet for the tuberculous. The committee urges that roast meat should be ground fine for dyspeptics, and that the articles of food in the salt-free diet should be varied to render it as appetizing as possible. The latest report of the committee was published in the Bull. Soc. Hed. des Hop. for June 28 and July $5,1907$.

\section{THE ABSORPTION AND ELIMINATION OF SOME COMMONLY USED DRUGS,}

\section{WITH PRACTICAL DEDUCTIONS FROM A KNOWLEDGE OF} THE SAME.

E. R. ZEMP, M.D.

Professor of Materia Medica and Therapentics. Pediatrics and Clinical Medicine, Tennessee Medical College. KNOXVILLE, TENN.

It is a regrettable fact that many phrsicians prescribe drugs either from habit or from hearsay. Even with the drugs prescribed many times daily some of their important actions are unknown or forgotten.

Certainly it is not necessary for me to state that a knowledge of the absorption and elimination of drugs is required before they can be administered intelligently. The fact that a physician is prevented from overdrawing his mortality account by an indulgent Providence should not make us any the less eager to bring about an improvement in a condition so easily improved. The trouble is we do not study our materia medica cnough. Many of us get our ideas of therapeutics from works on practice. This is sufficient to a degree only. The knowledge obtained from such a source can not replace tl:e knowledge of the phrsiologic actions of drugs that should be the basis of our therapeutic efforts.

That the systemic action of a drug is due to its absorption can not be disputed, and that the duration of its action is dependent on its elimination or oxidation is equally true. Drugs in the stomach produce no effect outside of local and reflex actions. It is only when they gain access to the system at large that their influence is felt. The knowledge of the rapidity with which a drug is absorbed and eliminated carries with it the knowledge of how often to repeat the dose of that drus. To prescribe a drug that is exceedingly flecting in its action at long intervals is as absurd as it is dangerous to prescribe at short intervals a drug that is slowly eliminated. Knowing the relation of the drug to both of these processcs gives us a happy control over its action.

The rapidity with which a drug is absorbed depends on a number of conditions. As a rule, the more soluble the drug the quicker is it absorbed. Alcoholic solutions are more rapidly absorbed than others. Drugs in solution when served hot are introduced into the system more rapidly than when served cold. Some drugs are so irritating to the stomach that the local disturbance produced entirely prevents absorption. Some drugs, but poorly absorbed themselves, form in the intestinal tract compounds that are rapidly and easily absorbed. So much for the drug.

As to the patient, the chicf factor influencing absorption is the eirculation. If the circulation is active absorption will be active. If the circulation is sluggish absorption will be slow. It may be entirely suspended. Absorption is peculiarly slow in dropsical conditions so that hypodermic medication is at times not only uncertain, but absolutely dangerous, for the various doses remain in the tissues for days only to be absorbed with the exudation after severe purgation, active diuresis or tapping. In this way the patient gets at one time all that has been given for several days. This could easily prove fatal, especially when the generally weak, condition of this class of patients is considered.

The condition of the stomach and intestines markedly affect the absorption of drugs. It is apparent that a chronic inflammation of the stomach, with its accompanying coat of riscid mucus, will retard absorption. 'The 